\title{
DIVERSIDADE GENÉTICA E SELEÇÃO DE INICIADORES ISSR EM UMA POPULAÇÃO NATURAL DE MANGABA (Hancornia speciosa Gomes) (APOCYNACEAE) ${ }^{1}$
}

\author{
DANIEL FERREIRA DA COSTA², FÁBIO DE ALMEIDA VIEIRA ${ }^{3}$, \\ CRISTIANE GOUVÊA FAJARDO ${ }^{4}$, KYVIA PONTES TEIXEIRA DAS CHAGAS 5
}

RESUMO-O conhecimento da diversidade genética de espécies nativas é de grande valia quando se objetiva o melhoramento e a conservação de populações naturais. Neste sentido, o objetivo deste trabalho foi selecionar iniciadores ISSR (inter repetições de sequências simples) para Hancornia speciosa (Apocynaceae), assim como quantificar a variabilidade genética em uma população natural. Foram amostrados 15 indivíduos de uma população localizada em Natal-RN. Amostras de caule foram coletadas para a posterior extração do DNA. Para a seleção, 19 primers ISSR foram testados, dos quais seis foram eficientes, apresentando locos nítidos e em maior número (UBC 808; UBC 810; UBC 826; UBC 827; UBC 841 e UBC 842), totalizando 63 locos. Desses, apenas 30 (47,62\%) apresentaram polimorfismo. O valor de PIC (conteúdo de informações polimórficas) para os primers selecionados atingiu a média de 0,37 , variando de 0,26 a 0,44 . A diversidade genética foi considerada baixa dentro da população, com o número de alelos observados $(n a=1,48)$, número de alelos efetivos ( $n e=1,32)$, índice de diversidade de Nei $(H e=0,18)$ e índice de Shannon $(I=0,26)$. Os padrões de diversidade alélica encontrados indicam a ocorrência de um gargalo populacional recente. A utilização de marcadores ISSR para Hancornia speciosa mostrou-se eficaz para a quantificação da diversidade genética dos indivíduos, servindo como aporte para estratégias e planos que visem à conservação e à manutenção da espécie.

Palavras-Chave: Gargalo genético, marcador molecular, conservação genética.

\section{GENETIC DIVERSITY AND ISSR INITIATORS SELECTION IN A NATURAL POPULATION OF MANGABA (Hancornia speciosa Gomes) (APOCYNACEAE).}

\begin{abstract}
The knowledge of genetic diversity of native species has great value when it aims at the improvement and conservation of natural populations. In that direction, the objective of this study is to select ISSR primers (inter simple sequence repeat) to Hancornia speciosa (Apocynaceae), as to quantify the genetic variability of a natural population. It was sampled 15 individuals of a population located in Natal/RN. Stem samples were collected for subsequent DNA extraction. For the selection, 19 IRSS primers were tested, six of them were effective, presenting clearer and numerous loci (UBC 808, UBC 810, UBC 826, UBC 827, UBC 841, UBC 842) totaling 63 loci. Of which, only 30 (47.62\%) presented polymorphism. The value of PIC (polymorphic information content) for the selected primers averaged 0.37, ranging from 0.26 to 0.44 . Genetic diversity was considered low in the population, with the number of observed alleles ( $n a=1.48)$, number of effective alleles $(n e=1.32)$, diversity index of Nei $(H e=0.18)$ and Shannon index $(I=0.26)$. The allelic diversity patterns found indicates the occurrence of a recent population bottleneck. The use of ISSR markers for Hancornia speciosa is effective as measuring the genetic diversity of individuals, working as a support for strategies and plans that aim the conservation and maintenance of the species.
\end{abstract}

Index terms: Bottleneck, molecular marker, genetic conservation.

\footnotetext{
'(Trabalho 246-15). Recebido em: 03-09-2014. Aceito para publicaçaõ em: 24-03-2015.

${ }^{2}$ Mestrando do curso de pós graduação em Ciências Florestais, UFRN, Unidade Especializada em Ciências Agrárias- Campus de Macaíba.danielcosta86@gmail.com

${ }^{3}$ Professor Dr. da UFRN, Unidade Especializada de Ciências Agrárias, Campus de Macaíba/RN. vieirafa@ufrnet.br

${ }^{4}$ Professora Dra . da UFRN, Unidade Especializada de Ciências Agrárias, Campus de Macaíba/RN. genegoista@yahoo.com.br

${ }^{5}$ Aluna de graduação em Engenharia Florestal, UFRN, Unidade Especializada de Ciências Agrárias, Campus de Macaíba/RN. kyviapontes@gmail.com
} 


\section{INTRODUÇÃO}

Há muito tempo apreciada pelos índios, a Hancornia speciosa Gomes (Apocynaceae), conhecida popularmente como mangaba, que em tupi-guarani significa "coisa boa de comer" (FERREIRA, 1973), vem sendo, ainda, bastante consumida pelas populações locais nas regiões de sua ocorrência. Além de seu fruto de sabor adocicado, a Hancornia speciosa possui látex de boa qualidade, o qual foi bastante explorado durante a Segunda Guerra Mundial, quando o mesmo foi, inclusive, exportado (VIEIRA NETO, 1994). Segundo Mota et al. (2008), o extrativismo e a comercialização da Hancornia speciosa é uma atividade predominantemente feminina, aumentando significativamente a contribuição das mulheres na renda e no patrimônio familiar, tendo, assim, um relevante papel socioeconômico nas comunidades locais.

Hancornia speciosa está amplamente distribuída no território brasileiro, podendo ser encontrada nos Cerrados das regiões Centro-Oeste, Sudeste e Norte, estando geralmente associada a regiões de solo pobre, ácido e com pouca matéria orgânica (LEDERMAN; BEZERRA, 2006). Além disso, pode também ser encontrada nos tabuleiros costeiros e nas baixadas litorâneas do Nordeste, onde é mais intensa sua extração para fins comerciais (VIDAL, 2010).

Em relação aos aspectos reprodutivos e fenológicos, essa espécie é considerada alógama e autoincompatível. De acordo com Darrault e Schlindwein (2005), a polinização é realizada por insetos da família Sphingidae (mariposas), sendo as flores visitadas principalmente ao anoitecer. Sua floração geralmente se estende de setembro a novembro, com o amadurecimento dos frutos ocorrendo de novembro a janeiro, podendo ocorrer também em outras épocas (LORENZI, 2008).

A utilização da análise molecular já é empregada com sucesso em estudos de diversidade genética que visam à conservação e ao melhoramento de espécies florestais e comerciais (REDDY et al., 2002; ASADIAR et al., 2012; LORENZONI et al., 2014). Os marcadores moleculares são vantajosos, quando comparados com os morfológicos, pois não sofrem a influência do ambiente, apresentam número elevado de polimorfismo e possibilitam estudos em qualquer fase do desenvolvimento da planta (FALEIRO, 2007). Marcadores do tipo RAPD (amplificação aleatória de DNA polimórfico) e sistemas isoenzimáticos foram utilizados com sucesso para análises de diversidade genéticas em populações de $H$. speciosa (MOURA et al., 2005; COSTA et al., 2011; MARTINS et al., 2012; SILVA et al., 2012; SILVA et al., 2013).

O uso de marcadores ISSR, para a análise genética, tem-se mostrado vantajoso se comparado a outros métodos. Esta constitui uma técnica de menor custo, não necessitando de conhecimento prévio do genoma da espécie objeto de estudo, gerando elevado número de locos polimórficos e alta reprodutibilidade (ZIETJIEWICZ et al., 1994; SANTOS et al., 2011). Estudos realizados com a espécie Rauvolfia serpentina L. (Apocynaceae), por exemplo, revelaram a eficiência dos marcadores ISSR em identificar diversidade genética em espécies da família (PILLAI et al., 2012).

Os marcadores ISSR são fragmentos de DNA obtidos a partir da amplificação via PCR (reação em cadeia da polimerase), utilizando-se de único primer, com tamanho entre 16 a 20 pares de bases (FALEIRO, 2007). Durante a PCR, o iniciador (primer) amplifica diversas regiões intermicrossatélites do DNA-alvo, produzindo múltiplos fragmentos de tamanhos variados (100 a 3.000 pb), que são posteriormente separados por eletroforese para a visualização dos fragmentos (locos). Por ser um marcador dominante, a presença de um loco pode significar um homozigoto dominante ou heterozigoto, enquanto sua ausência representa um homozigoto recessivo (ZIETJIEWICZ et al., 1994).

Devido a sua elevada importância econômica e distribuição natural, a Hancornia speciosa está sob intensa pressão antrópica, sendo essencial o conhecimento da diversidade genética das populações remanescentes para a elaboração de estratégias com fins preservacionistas. As informações geradas no presente estudo serão úteis para a conservação in situ como também pode contribuir para o processo de domesticação e de reprodução da espécie.

Diante disto, o objetivo deste trabalho foi selecionar primers ISSR para estudos de diversidade genética em populações naturais de Hancornia speciosa, assim como quantificar a variabilidade genética de uma população natural.

\section{MATERIAL E MÉTODOS}

A área de estudo localiza-se na cidade de Natal-RN, e pertence à área de proteção do Parque Estadual Dunas de Natal (coordenadas 5'51'18, 16 ”'S, 35¹1'57, 97"). Este é considerado o segundo maior parque urbano do Brasil e, de acordo com a UNESCO, constitui parte da Reserva da Biosfera da Mata Atlântica desde 1993. A vegetação característica é a Floresta Estacional Semidecidual (VELOSO et 
al., 1991).

Foram amostrados aleatoriamente, em uma área de aproximadamente $10.000 \mathrm{~m}^{2}, 15$ indivíduos adultos, assim considerados devido à presença de frutos. As amostras de caule foram extraídas da região do câmbio, acondicionadas em tubos plásticos de 2 $\mathrm{mL}$ contendo $\mathrm{CTAB} 2 \mathrm{x}$, posteriormente identificadas e transportadas ao Laboratório de Genética e Melhoramento Florestal - UFRN, Macaíba-RN. Em seguida, foram armazenadas em freezer a $-20^{\circ} \mathrm{C}$ até o momento da extração do DNA.

Cerca de $250 \mathrm{mg}$ de material caulinar foram submetidos à extração do DNA através do método CTAB proposto por Doyle e Doyle (1987), com modificações. Foram utilizados $100 \mathrm{mM}$ de Tris pH 8,0;1,4 M de NaCl; 20 mM de EDTA pH 8,0; $2 \%(\mathrm{p} / \mathrm{v})$ CTAB; $1 \%$ (p/v) PVP-40 e 0,2\% (v/v) de $\beta$-mercaptoetanol preaquecido a $65^{\circ} \mathrm{C}$ em banhomaria. O DNA foi armazenado em freezer a $-20^{\circ}$ até sua utilização.

Após a extração, a concentração total de DNA foi mensurada com o auxílio do espectrofotômetro Epoch $^{\mathrm{TM}}$, assim como por meio de eletroforese em gel de agarose a $1 \%$, empregando-se GelRed ${ }^{\mathrm{TM}}$ como corante.

Para a seleção dos iniciadores, foram testados 19 primers ISSR desenvolvidos pela Universidade de British Columbia (UBC primer set \#9, Vancouver, Canadá), com comprimentos entre 14 e 18 bases nitrogenadas. Para a reação da polimerase em cadeia, foi utilizado o Pré-mix IC (2x) da Phoneutria contendo tampão IC $(50 \mathrm{mM} \mathrm{KCl}, 10 \mathrm{mM}$ Tris$\mathrm{HCl} \mathrm{pH} 8,4$ e 0,1 TritonX-100, $\mathrm{MgCl}_{2} 2,0 \mathrm{mM}$ ), nucleotídeos (dATP, dCTP, dGTP, dTTP) e enzima termoestável Taq DNA Polimerase. Cada reação teve um volume final de $12 \mu \mathrm{L}$ por amostra, onde foram utilizados $2 \mu \mathrm{L}$ de primer $(2 \mu \mathrm{M}), 6 \mu \mathrm{L}$ de Pré-mix IC $(2 \mathrm{x}), 2 \mu \mathrm{L}$ de água ultrapura e $2 \mu \mathrm{L}$ de DNA (diluído a $2 \mu \mathrm{M}$ ). Para a seleção de primers, foi feito um "bulk" misturando-se $4 \mu \mathrm{L}$ de DNA concentrado de três indivíduos, aumentando assim as chances de amplificação de locos.

As reações ocorreram em Termociclador automático Veriti com 96 poços, onde as amostras foram inicialmente desnaturadas a $94^{\circ} \mathrm{C}$ por 2 minutos, seguidos de 37 ciclos, iniciando com 15 segundos a $94^{\circ} \mathrm{C}$, em seguida 30 segundos a $47^{\circ} \mathrm{C} \mathrm{e}$, posteriormente, $72^{\circ} \mathrm{C}$ por 1 minuto. Ao final de todos os ciclos, o processo foi finalizado por 7 minutos a $72^{\circ} \mathrm{C}$, e resfriado a $4^{\circ} \mathrm{C}$.

Após a PCR, foi realizada a eletroforese em cuba horizontal, em gel de agarose a 1,5\% $(\mathrm{p} / \mathrm{v})$, com tampão TAE 1X (Tris-Acetato EDTA), com a voltagem de $80 \mathrm{~V}$, por duas horas e meia. Foi utilizado o marcador molecular (Ladder) de 1.000 pares de base. Ao final da eletroforese, os géis foram fotografados sobre fonte de luz ultravioleta com o auxílio do sistema de fotodocumentação E-Box VX2, revelando os fragmentos de DNA corados com GelRed ${ }^{\mathrm{TM}}$. Os primers com melhor resolução e maior número de fragmentos foram selecionados para avaliar a diversidade genética da população amostrada, já os primers que apresentaram baixa definição e número baixo de locos foram desconsiderados.

Uma matriz binária foi elaborada a partir da presença (1) e da ausência (0) dos locos. Para estimar a eficiência dos primers na indicação de polimorfismo entre dois indivíduos, o PIC (conteúdo de informações polimórficas) foi calculado tendo como indicadores a presença e a ausência de locos. Para calcular o PIC, utilizou-se da fórmula proposta por Anderson et al. (1993):

$$
\mathrm{PIC}_{1}=1-\sum_{j=1}^{\mathrm{n}} \mathrm{P}_{\mathrm{\imath}}^{2}
$$

em que : Pij é a frequência do alelo "j” no marcador "i".

A diversidade genética foi estimada por meio do programa POPGENE versão 1.3 (YEH et al., 1997), tendo como parâmetro a análise do número de alelos observados $(n a)$, número de alelos efetivos (ne), diversidade genética de Nei (He) (1978) estimada com base na heterozigosidade esperada e Índice de Shannon $(I)$.

Com o intuito de verificar se houve diminuição recente e efetiva no tamanho populacional da espécie, utilizou-se do programa Bottleneck 1.2.02 (CORNUET; LUIKART, 1997). Foram utilizados os modelos de alelos infinitos (IAM) e o de passos de mutação (SMM) com base em Kimura e Cronw (1964), e Kimura e Otha (1978), respectivamente. De acordo com Luikart e Cornuet (1998), o modelo intermediário entre o IAM e SMM seria o indicado para inferir o acontecimento, ou não, de um possível gargalo genético na população, para os marcadores do tipo ISSR. Sendo assim, os dois modelos são recomendados para tal análise.

\section{RESULTADOS E DISCUSSÃO}

Os 19 iniciadores testados apresentaram fragmentos amplificados, mostrando, assim, que o método de extração de DNA empregado foi eficiente para a espécie. Dentre estes, destacaramse os iniciadores UBC808, UBC810, UBC826, 
UBC827, UBC841 (Figura 1) e UBC842 por apresentarem bandas nítidas e em maior número, totalizando 63 , com uma média de 10,5 locos por primer (Tabela 1). Dos 63 locos gerados, apenas 30 $(47,62 \%)$ apresentaram polimorfismo, sugerindo baixa diversidade genética dentro da população. Em estudos recentes para biribazeiro (Rollinia mucosa Baill), Lorenzoni (2014) encontrou 118 locos utilizando 20 primers ISSR, com média por primer de 5,9 locos. Santana (2011), pesquisando umbu-cajazeiras (Spondias sp.), testou 25 primers e obteve o número total de 249 locos com uma média de dez locos por primer. Pillai et al., realizando estudos com Rauvolfia serpentina L. (Apocynaceae), utilizaram 15 primers, e as amplificações resultaram em 91 locos, com média de seis por primer. O número médio de locos encontrados com os seis primers utilizados está dentro do esperado para marcadores ISSR.

O PIC atingiu o valor médio de 0,37 , com variação de 0,26 a 0,44 (Tabela 1). De acordo com XIE et al. (2010), o valor do PIC varia de 0 a 0,25 para marcadores que são considerados pouco informativos, de 0,25 a 0,5 para marcadores moderadamente informativos e acima de 0,5 para marcadores que apresentam alto conteúdo informativo. Este valor auxilia na classificação dos primers conforme a eficiência na detecção do polimorfismo, servindo de parâmetro para a seleção dos primers. Assim, no presente estudo, pode-se considerar que a eficiência dos primers em indicar polimorfismo entre dois indivíduos é moderada. Li et al. (2013), estudando populações nativas de Prunus armeniaca L. (Rosaceae) no nordeste da China, encontraram valores de PIC variando entre 0,15 e 0,27 , com a média de 0,21 ; sendo assim, os primers foram considerados pouco informativos. Estudando uma população natural de Hancornia speciosa com marcadores dominantes tipo RAPD, Silva et al. (2012) obtiveram o valor médio de 0,32 , sendo os primers considerados como moderadamente informativos. Logo, as informações geradas pelos seis primers utilizados no presente estudo foram consideradas suficientes para avaliar a diversidade genética entre os 15 indivíduos amostrados.

$\mathrm{O}$ índice de diversidade genética de $\mathrm{Nei}(\mathrm{He})$, assumindo o equilíbrio de Hardy-Weinberg, foi de 0,18 , com o número de alelos observados de 1,48 , e os alelos efetivos, de 1,32. O índice de Shanonn (I) atingiu o valor de 0,26 . Os valores encontrados para o He e para o I são indicativos de baixa diversidade genética dentro da população. Em sua pesquisa com Palicourea coriacea (Rubiaceae), Barbosa et al. (2010), utilizando marcadores RAPD, encontraram para $H e$ o valor de 0,30 , e o $I=0,56$, e concluíram que a espécie apresentou alta diversidade genética. Costa et al. (2011), avaliando a diversidade genética em genótipos de Hancornia speciosa no BAG (Banco ativo de germoplasma) de Sergipe, encontraram valores médios para $\mathrm{He}$ e $I$, respectivamente 0,17 e 0,25 , sendo semelhantes aos encontrados no presente estudo. Martins et al. (2012), utilizando marcadores codominantes, observaram alta diversidade genética para a espécie com o $\mathrm{He}$ de 0,36 .

A baixa variabilidade genética encontrada na população estudada pode estar relacionada ao seu isolamento geográfico, que dificulta o fluxo gênico entre populações e favorece o aumento dos cruzamentos entre indivíduos aparentados. A pressão antrópica, devido à proximidade com a área urbana, é outro fator que pode influenciar nos índices de diversidade, como relatado por Costa et al. (2011). A alta diversidade genética encontrada por Martins et al. (2012) pode estar relacionada ao tipo de marcador utilizado, pois marcadores isoenzimáticos diferenciam locos homozigotos de heterozigotos (FALEIRO, 2007), aumentando assim o número de informações geradas. Estudos relacionados à dispersão de pólen e sementes para a Hancornia speciosa são incipientes, sendo essenciais para o entendimento da distribuição da diversidade genética dentro e entre populações.

A presença de gargalos genéticos na população em estudo foi observada a partir do modelo SMM (Tabela 2). Este modelo revelou excesso de heterozigosidade, indicando um possível decréscimo populacional em curto período de tempo (LUIKART; CORNUET, 1998). Em situação em que há diminuição drástica no tamanho da população, espera-se que o número de alelos seja perdido mais rapidamente do que a diversidade genética, sendo encontrado nas populações um número excessivo de heterozigotos (LUIKART; CORNUET, 1998).

Tratando-se de espécie alógama, era esperada alta diversidade genética entre os indivíduos amostrados. Possivelmente, a baixa variabilidade genética encontrada dentro da população de Hancornia speciosa pode estar relacionada à grande fragmentação das áreas de sua ocorrência, em especial nos grandes centros urbanos, onde o decréscimo repentino no número de indivíduos ocasionou diminuição da diversidade genética dentro da população. Com isso, estratégias para a conservação das populações naturais remanescentes são necessárias para a manutenção da variabilidade genética da espécie, assim como a criação de corredores ecológicos ligando os fragmentos, promovendo assim aumento do fluxo gênico, e consequentemente, da variabilidade genética. 


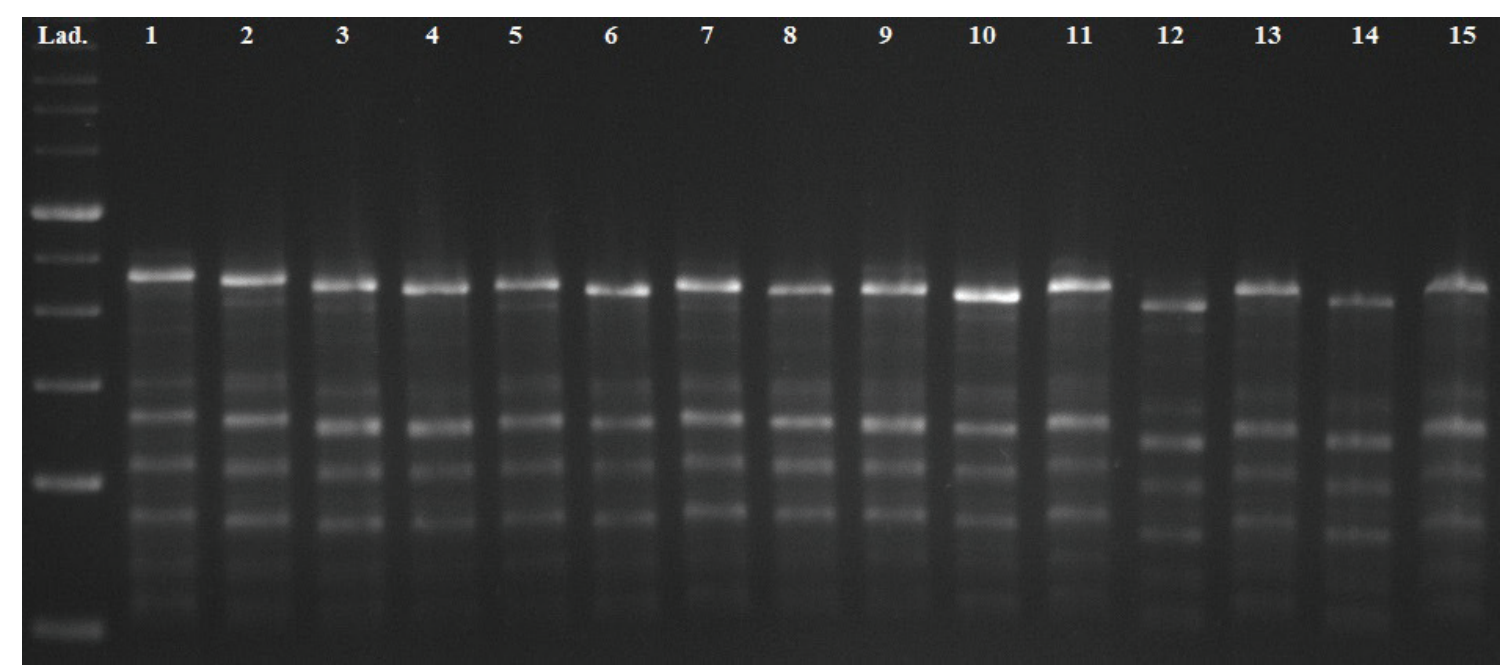

FIGURA 1- Fragmentos resultantes da amplificação dos 15 indivíduos de $H$. speciosa pelo primer UBC 841. $\mathrm{Lad}=$ Ladder, com mil pares de bases nitrogenadas.

TABELA 1-Primers ISSR, sequência de nucleotídeos, número de locos e valor de PIC (conteúdo de informações polimórficas) de cada primer.

\begin{tabular}{llcc}
\hline \multicolumn{1}{c}{ Primers ISSR } & Sequência (5'-3') & Locos & PIC \\
\hline UBC 808 (AG)8-C & AGAGAGAGAGAGAGAGC & 11 & 0,37 \\
UBC 810 (GA)8-T & GAGAGAGAGAGAGAGAT & 08 & 0,43 \\
UBC 826 (AC)8C & ACACACACACACACACC & 10 & 0,30 \\
UBC 827 (AC)8G & ACACACACACACACACG & 13 & 0,41 \\
UBC 841 (GA)8-YC & GAGAGAGAGAGAGAGAYC & 10 & 0,26 \\
UBC 842 (GA)8-YG & GAGAGAGAGAGAGAGAYG & 11 & 0,44 \\
\hline \multicolumn{1}{c}{ Média } & & $\mathbf{1 0 , 5}$ & $\mathbf{0 , 3 7}$ \\
\hline
\end{tabular}

$\mathrm{R}=$ purina $(\mathrm{A}$ ou $\mathrm{G})$ e $\mathrm{Y}=$ pirimidina $(\mathrm{C}$ ou $\mathrm{T})$.

TABELA 2- Testes de equilíbrio entre mutação e deriva genética para a população de Hancornia speciosa sobre os modelos IAM e SMM.

\begin{tabular}{|c|c|c|c|c|c|}
\hline \multicolumn{3}{|c|}{ IAM } & \multicolumn{3}{|c|}{ SMM } \\
\hline$n$ & $\mathrm{Hd} / \mathrm{He}$ & $P$ & $n$ & $\mathrm{Hd} / \mathrm{He}$ & $P$ \\
\hline 29,30 & $39 / 24$ & 0,112 & 35,12 & $39 / 24$ & $0,00350^{*}$ \\
\hline
\end{tabular}

$\mathrm{n}=$ número esperado de locos com excesso de heterozigosidade sob o respectivo modelo; $\mathrm{Hd} / \mathrm{He}=$ número de locos com déficit de heterozigosidade e excesso de heterozigosidade; $\mathrm{P}=$ probabilidade; * = significativo a 5\% probabilidade de erro. 


\section{CONCLUSÃO}

Os seis primers de ISSR selecionados no presente trabalho são eficientes para identificar polimorfismo molecular entre os indivíduos de Hancornia speciosa.

Há baixa diversidade genética na população analisada, sugerindo diminuição drástica e recente no número de indivíduos da população.

\section{REFERENNCIAS}

ANDERSON, J. A.; CHURCHILL, G. A.; AUTRIQUE, J. E.; TANKSLEY, S. D.; SORRELLS, M. E. Optimizing parental selection for genetic linkage maps. Genome, Ottawa, v. 36, p. 181-186, 1993.

ASADIAR, L. S; RAHMANI, F.; SIAMI, A. Assessment of genetic diversity in the Russian olive (Elaeagnus angustifolia) based on ISSR genetic markers. Revista Ciência Agronômica, Belém, v. 44, n.2, p. 310-316, 2012.

BARBOSA T. C. et al. Genetic characterization of natural populations of the medicinal plant Palicourea coriacea (Rubiaceae) with molecular markers Genetics and Molecular Research, Ribeirão Preto, v. 9, n. 2, p. 695-704, 2010.

CORNUET J. M., LUIKART G. Description and power analysis of two tests for detecting recent population bottlenecks from allele frequency data. Genetics, Bethesda, v.144, n.4, p. 2001-2014, 1997.

COSTA, T. S.; SILVA, A. V. C.; LÉDO, A. S. Diversidade genética de acessos do banco de germoplasma de mangaba em Sergipe. Pesquisa Agropecuária Brasileira, Brasília, v. 46, n. 5, p.499-508, 2011.

DARRAULT, R. O.; SCHLINDWEIN, C. Limited fruit production in Hancornia speciosa (Apocynaceae) and pollination by nocturnal and diurnal insects with long mouth parts. Biotropica, New York, v. 37, n. 3, p. 381-388, 2005.

DOYLE, J. J.; DOYLE, J. L. Isolatin of plant DNA from fresh tissue. Focus, Rockville, v. 12, n. 1, p. 13-15. 1987.
FALEIRO, F.G. Marcadores genético-moleculares aplicados a programas de conservação e uso de recursos genéticos. Planaltina: Embrapa Cerrados, 2007. p. 102.

FERREIRA, M. B. Frutos comestíveis do Distrito Federal: III. pequi, mangaba, marolo e mamãozinho. Cerrado, Brasília, v. 5, n. 20, p. 22-25, 1973.

KIMURA M., CROW J. The number of alleles that can be maintained in a finite population. Genetics, Bethesda, v.49, p. 725-738, 1964.

KIMURA M., OTHA T. Stepwise mutation model and distribution of allelic frequencies in a finite populations. Proceedings of the National Academy of Sciences of the USA, Washington, v.75, n.6, p. 2868-2872, 1978.

LEDERMAN, I. E.; BEZERRA J. E. F. Situação atual e perspectivas da cultura. In: SILVA, J. F.; LÉDO A. S. (Ed.). A cultura da mangaba. Aracaju: Embrapa Tabuleiros Costeiros, 2006. p. 247-253.

LI M.; ZHAO Z.; MIAO X. J. Genetic variability of wild apricot (Prunus armeniaca L.) populations in the Ili Valley as revealed by ISSR markers. Genetic Resources and Crop Evolution, Dordrecht, n.60, p. 2293-2302, 2013.

LORENZI, H. Árvores brasileiras: manual de identificação e cultivo de plantas arbóreas nativas no Brasil. 5.ed. Nova Odessa: Instituto Plantarum, 2008. v.1, p.47.

LORENZONI, R. M.; SOARES, T.C.B.; SANTIAGO, V. F.; SILVA, J. A.; COELHO, R. I. Utilização de marcadores ISSR na avaliação da divergência genética entre acessos de Biribazeiro. Revista Brasileira de Fruticultura, Jaboticabal, v.36, p.251257, 2014. Número Especial.

LUIKART, G.; ALLENDORF, F. W.; CORNUET, J. M.; SHERWIN, W. B. Distortion of allele frequency distributions provides a test for recent population bottlenecks. Journal of Heredity, New York, v.89, n.3, p. 238-247, 1998.

MARTINS, J. V.; MARTINS, L. S. S; VEASEY, E. A.; LEDERMAN, I. E.; SILVA, E. F. Diversity and genetic structure in natural populations of Hancornia speciosa var. speciosa Gomes in northeastern Brazil. Revista Brasileira de Fruticultura, Jaboticabal, v. 34, n. 4, p. 1143-1153, 2012. 
MOTA, D. M.; SCHMITZ, H.; SILVA JÚNIOR, J. F. S.; RODRIGUES, R. F. A.; ALVES, J. N. F. O extrativismo de mangaba é "trabalho de mulher"? Duas situações empíricas no Nordeste e Norte do Brasil. Novos Cadernos NAEA, Belém, v. 11, n. 2, p.155-168, 2008.

MOURA, N.F.; CHAVES, L.J.; VENCOVSKY, R.; ZUCCHI, M.I.; PINHEIRO, J.B.; MORAIS, L.K. de; MOURA, M.F. Seleção de marcadores RAPD para o estudo da estrutura genética de populações de Hancornia speciosa Gomez. Bioscience Journal, Washington, v. 21, p. 119-125, 2005.

NEI, M. Estimation of average heterozygosity and genetic distance from a small number of individuals. Genetics, Bethesda. n. 89, p. 583-590, 1978.

PILLAI, P. P.; SAJAN, J. S, MENON K. M.; JAYAKUMAR, K. S. P.; SUBRAMONIAM, A. ISSR analysis reveals high intraspecific variation in Rauvolfia serpentina L. - A high value medicinal plant. Biochemical Systematics and Ecology, Oxford, v. 40, p. 192-197, 2012.

REDDY, M. P; SARLA, N; SIDDIQ, E. A. Inter simple sequence repeat (ISSR) polymorphism and its application in plant breeding. Euphytica, Dordrecht, n.128, p 9-17, 2002.

SANTANA, I. B. B.; OLIVEIRA, E. J.; SOARES FILHO, W. S.; RITZINGER, R.; AMORI M , E. P.; COSTA, M. A. P. C.; MOREIRA, R. F. C. Variabilidade genética entre acessos de umbucajazeira mediante análise de marcadores ISSR. Revista Brasileira de Fruticultura, Jaboticabal, v. 33, n. 3, p. 868-876, 2011.

SANTOS, L. F.; OLIVEIRA, E. J.; SILVA, A. S. ISSR Markers as a tool for the assessment of genetic diversity in Passiflora. Biochemical Genetics, Dordrecht, n. 49, p. 540-554, 2011.
SILVA, A. V. C.; RABBANI, A. R. C.; SENAFILHO, J. G. S.; ALMEIDA. C. S.; FEITOSA, R. B. Genetic diversity analysis of Mangaba (Hancornia speciosa Gomes), na exotic Brazilian tropical species. Tropical and Subtropical Agroecosystems, Mérida, v. 15, p. 217-225, 2012.

SILVA, S. A.; CRUZ, E. M. O.; REIS, R. V.; FERREIRA, C. F.; PASSOS, A. R. Caracterização morfológica e Molecular de genótipos de Mangaba. Revista Brasileira de Fruticultura, Jaboticabal, v. 35, n. 4, p.1093-1100, 2013.

VELOSO, H.P.; RANGEL FILHO, A.L.R.; LIMA, J.C.A. Classificação da vegetação brasileira, adaptada a um sistema universal. Rio de Janeiro: IBGE - Departamento de Recursos Naturais e Estudos Ambientais, 1991. p. 124.

VIDAL, R. F. Qualidade, compostos bioativos e atividade antioxidante de genótipos de mangabeiras (Hancornia speciosa GOMES) nativos do litoral Cearense. 2010. 92 f. Dissertação (Mestrado) - Universidade Federal do Ceará, Fortaleza, 2010.

VIEIRA NETO, R. D. Cultura da mangabeira. Aracaju: Embrapa CPATC, 1994. p.16. (Circular Técnica, 2).

XIE,W.; ZHANG, X.; CAI, H., LIU,W.; PENG, Y. Genetic diversity analysis and transferability of cereal EST-SSR markers to orchardgrass (Dactylis glomerata L.). Biochemical Systematics and Ecology, Oxford, v. 38, p. 740-749, 2010.

YEH, F. C.; YANG, R. C.; BOYLE, T. B. J.; YE, Z. H.; MAO, J. X. POPGENE, theuser-friendly shareware for population genetic analysis molecular biology and biotechnology center. Edmonton: University of Alberta, 1997.

ZIETJIEWICZ, E.; RAFALSKI, A.; LABUDA, D. Genome fingerprinting by simple sequence repeat (SSR)-anchored polymerase chain reaction amplification. Genomics, San Diego, n. 20, p. 176183, 1994. 